DOI: $10.17805 /$ trudy.2017.2.4

\title{
ГЕНЕЗИС СУПРУЖЕСТВА НА ЗАКЛЮЧИТЕЛЬНОМ ЭТАПЕ РАЗВИТИЯ ЧЕЛОВЕКА
}

\author{
Е. В. Гурова \\ Московский гуманитарный университет
}

\begin{abstract}
Аннотация: В статье рассматривается специфика супружеских отношений в период геронтогенеза. Показана значимость семейных отношений в жизни пожилого человека, трансформация функций семьи пожилого человека, а также ролевой структуры.
\end{abstract}

Ключевые слова: геронтология; геронтогенез; поздний возраст; супружество; пожилой человек; семейные отношения

\section{GENESIS OF MATRIMONY AT THE FINAL STAGE OF HUMAN DEVELOPMENT}

\author{
E. V. Gurova \\ Moscow University for the Humanities
}

\begin{abstract}
The article examines the specific character of marital relationships during the period of gerontogenesis. The importance of family relationships in the life of an elderly person, the transformation of family functions for an elderly person, and of role structure are also shown in the paper.

Keywords: gerontology; gerontogenesis; late age; matrimony; elderly person; family relationships

Семейные и супружеские отношения пожилых людей долгое время оставались на периферии научного интереса. В психологии семейных отношений рассматриваются в основном проблемы создания и функционирования молодежной семьи или семьи среднего возраста. И практически не рассматривается проблематика, связанная с функционированием пожилой семьи, несмотря на то, что продолжительность существования такой семьи значительная.

Пожилые семьи в большей степени изучаются в социологии и социальной геронтологии, при этом основной акцент в социогеронтологических работах делается на вопросы поддержки пожилых родителей и ухода за ними, оказание медико-социальной помощи, рассматриваются и правовые аспекты социальной защиты и поддержки пожилых людей, вопросы государственной политики в отношении пожилых граждан, а также положение пожилого человека в семье.
\end{abstract}


В массовом сознании бытуют социальные негативные стереотипы в отношении к пожилым семьям. Они отражают общие тенденции и ценности развития института семьи в конкретном социальном контексте.

Считается, что одной из главных функций семьи является репродуктивная функция - рождение и воспитание детей. Эти стереотипы исключают многофункциональность жизнедеятельности семьи, обесценивают социальное бытие пожилых семей. В сознании людей формируется деформированный социальный портрет пожилой семьи, как нечто пассивное, беспомощное, бесполезное для общества.

Данные современных исследований говорят о том, что в сознании людей происходит консервация представлений о повседневных проблемах пожилых супружеских пар. Во многом это происходит из-за существования в обществе негативных стереотипов старости, создания средствами массовой коммуникации образа немощного, больного пожилого человека, нуждающегося в медицинской и социальной помощи. Исследование социальных представлений студентов и работающих взрослых о пожилых людях показало, что в целом они имеют негативную направленность. При этом в ответах студентов были преимущественно негативные метафоры, в то время как работающие взрослые оценивали пожилых людей и с позитивной стороны (Емельянова, Зинина, 2014).

Также можно говорить и о искаженном восприятии семьи пожилого человека. В исследовании М. Э. Елютиной было выявлено, что семья пожилого человека воспринимается в общественном сознании как: пассивная и беспомощная; некая герметизированная, замкнутая и приватная среда, в которой отсутствует динамика становления и обновления; объект материальной, моральной и физической помощи в настоящем или в ближайшем будущем; безликая слитность: происходит стирание дифференциации супружеских ролей - муж и жена объединяются словом «старики» или «они»; аутсайдеры социальной жизни, как домашние «хосписы» с характерной «разряженностью» жизни. Основными проблемами повседневной жизни пожилых супругов, по мнению респондентов, являются здоровье и материальная обеспеченность. Внимание супругов сосредоточенно теперь на внутренних бытовых проблемах - прежде всего, это дачно-огородные дела и воспитание внуков. Межличностные отношения пожилых супругов и связанные с ним проблемы не осознаются и не отражаются в сознании респондентов. М. Э. Елютина подчеркивает, что этот пласт семейной жизни на данном возрастном этапе представляет собой «слепую зону», не обладающую публичностью выражения, проблемной напряженностью. Автор делает предположение, что такое игнорирование зоны межличностного общения может быть своего рода защитной реакцией на возрастную перспективу «совместного старения» (Елютина, 2010). 
Вместе с тем, можно говорить о том, что сейчас происходит принципиально новое открытие старости. Этот период человеческой жизни стал рассматриваться как равноправный в ряду других психологических возрастов, содержащий не только инволюционные изменения, процессы распада, а и эволюционные изменения, свойственные любому другому возрасту. Они имеют свою специфику и свидетельствуют о том, в старости развитие психики человека не прекращается.

Исследования отечественных ученых Г. С. Абрамовой (Абрамова, 2004), Л. В. Бороздиной (Бороздина, Молчанова, 2001), М. В. Ермолаевой (Ермолаева, 2007), О. В. Красновой (Краснова, 2009) А. Г. Лидерса (Лидерс, 2004), И. В. Шаповаленко (Шаповаленко, 2011) и др. показывают, что в условиях вытеснения пожилого человека из общественной жизни, утраты здоровья, семья становится тем местом, где пожилой человек находит поддержку и понимание.

Семья для пожилого человека становится источником стабильности, защищенности, прочности, радости, влияет на качество жизни и ее оценку. Отношения с детьми, внуками помогают пожилому человеку определить свое место в новых условиях жизни. Сосредоточение пожилых людей на интересах узкого социального пространства собственной семьи является одним из механизмов жизненной активности человека в старости. При этом способность человека прогрессивно развиваться, вести активный образ жизни, быть включенным в социальную жизнь общества, вести здоровый образ жизни является важным фактором противостояния наступлению старости. Теряя физические силы, человек может сохранять способность прогрессивного развития как личность (Гребенникова, 2014).

Семья, полноценные семейные отношения помогают пожилым людям принять свою старость и достойно прожить заключительный период своей жизни в кругу самых близких ему людей. Что же представляет из себя семья пожилого человека? Согласно периодизации жизненного цикла семьи Р. Хилла, пожилые супруги переживают стадию после отделения детей, стадию «вылета детей из семьи», «стадию пустого гнезда» (см.: Карабанова, 2007). Специфика этой стадии определяется, прежде всего, тем, что супруги, или один из них, входит в заключительный период своего онтогенетического развития. Как отмечает Л. И. Анцыферова, построение нового образа жизни, сопряжено со значительным напряжением адаптивных возможностей пожилого человека, его интеллектуальных усилий, мотивацией достижения, поиском новых опор в своем жизненном мире (Анцыферова, 2004). Смена общественной позиции, выход на пенсию, сужение социального мира, возрастно-психологические изменения пожилого человека определяют во многом характер его семейных отношений.

Жизненный цикл семьи на данном этапе определяется такими событиями, как рождение внуков и освоение в этой связи новых социальных 
ролей бабушки/дедушки, повышением зависимости от взрослых детей и необходимостью принятия помощи от них, изменением сексуальных отношений, переживанием утраты супруга и необходимостью построения нового образа жизни в условиях вдовства или нового брака.

Ученые отмечают стабильность супружеских отношений в этом возрасте, обостренную потребность супругов друг в друге, особое осознание ценности брака, чувстве гармонии, меньшей напряженности. Одиночество - пугающая перспектива, которую пожилые люди редко выбирают добровольно. Характер отношений супругов в пожилом возрасте во многом определен их длительной историей совместного проживания.

В исследовании Д. В. Латышева было установлено, что пожилая семья перестает быть детоцентристской структурой. В ней идет интенсивная выработка новых паттернов взаимодействия как с внешней, так и внутренней средой, поиск личностно-ориентированных смыслов. Формируется особый режим взаимодействия и внутри семьи, и за ее пределами. Изменяется идеология семьи в направлении закрытости. Внешняя граница пожилой семьи становятся более жесткой. Стратегия экспансии сменяется фокусированием на собственных, внутрисемейных проблемах (Латышев, 2007).

Во взаимодействии мужа и жены усиливается взаимозависимость, симбиотичность пожилых супругов, формируются общие механизмы репрезентации мира, в котором семья пожилых людей функционирует, общие фильтры, способствующие выбору той или иной интерпретации внешних событий. Супруги переживают схожие психические состояния. Все это помогает пожилым людям найти необходимые стратегии выхода из кризисных ситуаций.

Изменяется режим существования современных пожилых семей. Социологические исследования показывают, что большинство российских пожилых семей принадлежит к социально уязвимым группам. Их материальное положение хотя и дифференцированно, но остается весьма скромным. Размер государственной пенсии не позволяет им вести независимую материальную жизнь, многие семьи пожилых людей получают пособия, дотации, субсидии.

Изменяются функции пожилой семьи. Утрачивается репродуктивная функция, ослабляется воспитательная, снижена функция ретрансляции и передачи культурного опыта, ценностей, знаний (происходит процесс переоценки ценностей в современном обществе). Видоизменяется сексуально-эротическая функция. Старение организма сказывается на характере интимной жизни, половое влечение заметно ослабевает, но сила и скорость затухания зависит от ряда факторов, прежде всего состояния здоровья пожилого человека. Более сильно выражена потребность в 
ласке, нежности, поддержке, заботе.

Происходит усиление функции эмоциональной поддержки и принятия или так называемая психотерапевтическая функция. Пожилые супруги отличаются проявлением повышенной заботы друг о друге, вниманием и теплотой отношений, сочувствием и взаимопомощью в бытовых делах, супруги стараются оградить спутника жизни от лишних волнений. Если на раннем этапе жизни семья выступает своеобразной стартовой площадкой для человека, то на завершающем - последним прибежищем. Вытесненный из системы общественной жизни, в условиях неопределенности социальных ожиданий в отношении себя, равнодушия и пренебрежения окружающих (эйджизм), с огромными потерями (здоровья, достатка, уважения, статуса, физической силы и внешней привлекательности, позитивного отношения со стороны окружающих и т. д.) пожилой человек в семье может найти поддержку и понимание.

Возрастает значение функции духовного общения. Супруги становятся родными и близкими по долгим прожитым годам, по общим человеческим ценностям, образу жизни и мысли, по взглядам, привычкам и вкусам.

Реализуется регенеративная функция: семья пожилого человека это мостик в родственных связях, связующее звено в отношениях младших и старших поколений, хранитель истории семьи, традиций, семейных мифов и воспоминаний.

Изменяются и ролевая структура пожилой семьи. Практически одинаковый размер пенсии пожилых людей освобождает мужчину от роли кормильца, что влечет за собой и перераспределение вопроса властных полномочий в семье. Учитывая, что с возрастом у женщин под действием тестостерона начинает проявляться такие мужские черты как властность, агрессивность, активность, напористость и т. д., роль главы семьи, как правило, в пожилой паре принадлежит женщинам. Она ведет семейный бюджет, является хозяйкой дома, она же в большей степени принимает участие в воспитании внуков, а также в силу большей эмоциональной чувствительности выступает и семейным психотерапевтом. Bсе это позволяет пожилым женщинам успешнее адаптироваться к процессу старения, к новому социальному статусу пенсионера, ощущать свою востребованность в семье. Таким образом, в пожилых семьях, как отмечает О.А.Карабанова, происходит «тихая бархатная революция», и вся полнота семейной власти оказывается в женских руках (Карабанова, 2007: 35).

Такой вариант динамики ролевой структуры семьи обедняет и схематизирует супружеские отношения, выходом из создавшейся ситуации может служить поиск новых значимых и доступных сфер самореализации, преодоление вынужденной праздности своего существования.

Л. И. Анцыферова предполагает, что успешное прохождение лично- 
стью возрастных периодов связано с экспериментированием с жизненными ролями. Роль на некоторое время определяет личностный способ существования человека, он ведет себя в соответствии с правилами, заключающимися в этой роли. Когда возникает рассогласование между требованиями роли и возможностями индивида (социальными или психологическими), он пытается опробовать себя в новых ролях. При этом пережитые человеком разные формы личностного существования не исчезают, а сохраняются в его внутреннем мире в виде «эскизов» виртуальных личностей. Эти фрагментарные личности в позднем возрасте помогают субъекту обрести себя в новом качестве и наполнить ее новым смыслом. В результате выхода не пенсию человек оказывается в ситуации неопределенности. И теперь человек сам должен организовать свое настоящее и будущее, наметить новую жизненную программу. Именно в такие моменты актуализация виртуальных личностей может помочь человеку начать новую деятельную жизнь (Анцыферова, 2004). В связи с этим, особое значение в жизни пожилых супругов имеет прародительство.

Продолжительная супружеская жизнь изменяет и чувства супругов, теряется чувство первооткрытия, новизны, неизведанности. С возрастом пылкая любовь, с которой они когда-то создавали семью, уступает месту не менее прекрасному чувству тесной привязанности и крепкой дружбе. Это позволяет пожилым супругам принимать друг друга такими, каким они есть, со всеми недостатками.

Поведение пожилого человека в семье определяется многими факторами, но в значительной мере его личностными особенностями, мотивационным здоровьем - наличием интереса к жизни и потребностью жить дальше, а также типом отношения к факту своего старения.

\section{СПИСОК ЛИТЕРАТУРЫ}

Абрамова, Г. С. (2004) Психология человеческой жизни: Исследования геронтопсихологии. М. : Издательский центр «Академия».

Анцыферова, Л. И. (2004) Развитие личности и проблемы геронтопсихологиИ. М. : ИПРАН.

Бороздина, Л. В, Молчанова, О. С. (2001) Самооценка в разных возрастных группах: от подросков до престарелых. М. : Проект-Ф.

Елютина, М. Э. (2010) Супружеские отношения в пожилом возрасте // Социологические исследования. № 11. С. 83-92.

Емельянова, Т. П., Зинина, А. А. (2014) Уровни репрезентации престарелых людей в российском обществе // Знание. Понимание. Умение. № 3. С. 213-223.

Ермолаева, М. В. (2007) Современные технологии психологического консультирования и психотерапии пожилых людей. М. : Издательство 
Московского психолого-социального института ; Воронеж : Издательство НПО «МОДЭК».

Латышев, Д. В. (2007) Социальная идентификация пожилой семьи в современном российском контексте : автореф. дис....канд. социол. наук. Саратов.

Лидерс, А. Г. (2004) Семья как психологическая система. М. : Обнинск.

Карабанова, О. А. (2007) Психология семейных отношений и основы семейного консультирования. М. : Гардарики.

Краснова, О.В. (2009) Особенности восприятия современной социальной ситуации пожилыми // Психология зрелости и старения. № 2. С. 13.

Психология семьи (2014) : учебник для студ. учреждений высш. проф. образования / Н. В. Гребенникова, Е. В. Гурова, Е. И. Захарова и др.; под ред. Е. Г. Сурковой. М. : Издательский центр «Академия».

Шаповаленко, И. В., Ковалева, Т.А. (2011) Толерантное отношение к процессу старения как позиция личности // Социальная политика и социология. № 7(73). С. 205-211.

Дата поступления: 15.03.2017 2.

Гурова Елена Васильевна - кандидат педагогических наук, профессор кафедры общей психологии и истории психологии Московского гуманитарного университета. Адрес: 111395, Россия, г. Москва, ул. Юности, д. 5. Тел.: +7 (499) 374-67-20. Эл. адрес: opsy@mail.ru

Gurova Elena Vasilyevna, Candidate of Pedagogy, Professor of Department of General Psychology and History of Psychology of Youth, Moscow University for the Humanities. Postal address: 5, Yunosti St., Moscow, Russian Federation 111395. Tel.:+7 (499) 374-67-20. E-mail: opsy@mail.ru

\section{Для цитирования:}

Гурова Е. В. Генезис супружества на заключительном этапе развития человека [Электронный ресурс] // Научные труды Московского гуманитарного университета. 2017, № 2. URL: http://journals.mosgu.ru/trudy/article/view/450 (дата обращения: дд.мм. гг.). DOI: 10.17805/trudy.2017.2.4 